
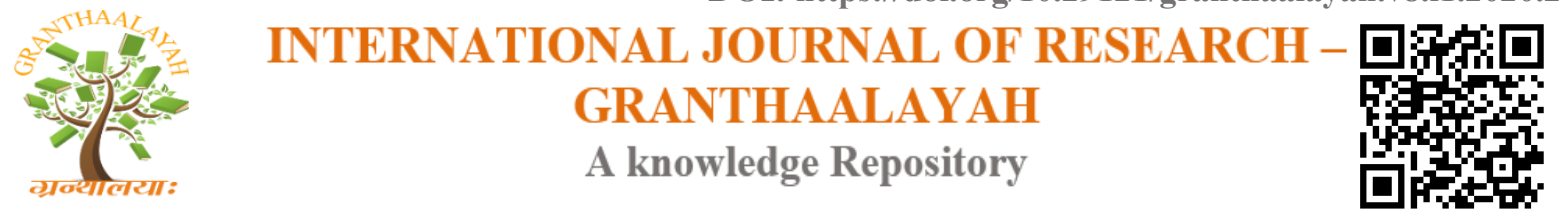

Social

\title{
PROBLEM SOLVING ATTITUDE AND CRITICAL THINKING ABILITY OF STUDENTS
}

\author{
Dr. Jerald C. Moneva *1, Dr. Rey G. Miralles ${ }^{2}$, James Z. Rosell ${ }^{3}$ \\ ${ }^{*} 1,3$ Mandaue City Division- Department of Education, Mandaue City, Cebu Philippines \\ ${ }^{2}$ Senior High School, Mandaue City, Cebu, Philippines
}

\begin{abstract}
Problem solving attitude is one of the most important aspect of the students in handling problems that they encountered. Meanwhile, critical thinking ability is also an important skill of the students in dealing and analyzing the problems and to it appropriately. The study used descriptive correlation design to determine the relationship between problem solving attitude and critical thinking ability of the students. The study has 240 respondents from the different strands (ABM, HUMSS, GAS, TVL and STEM) in certain senior high school: Mandaue City, Cebu, Philippines. The tool used in this study in getting the information and data collection is rating scale questionnaire. All the data are analyzed using weighted mean and chi-square to show the result. The result shows that the problem solving attitude is significantly associated to the critical thinking ability of the students. Students who have high level of problem solving attitude will become successful ones someday, because they don't get affected in their problems instead, they solved it right away with their critical thinking. Students' critical thinking ability is very useful in solving and analyzing their problems.
\end{abstract}

Keywords: Academic Performance; Critical Thinking; Knowledge; Problems; Problem Solving; Skills.

Cite This Article: Dr. Jerald C. Moneva, Dr. Rey G. Miralles, and James Z. Rosell. (2020). "PROBLEM SOLVING ATTITUDE AND CRITICAL THINKING ABILITY OF STUDENTS." International Journal of Research - Granthaalayah, 8(1), 138-149. https://doi.org/10.29121/granthaalayah.v8.i1.2020.261.

\section{Introduction}

Students experience problems from time to time. some students cannot handle their problems and end up of having stress and discouragement in their studies. students feel in that way, because they are lack of problem solving attitude. problem solving attitude is the skill of students who does not easily give up on their problems instead, they think critically finding a good solution to solve their problems. meanwhile, students also need a critical thinking ability for them to think clearly and calmly in solving their problems. problem solving attitude and critical thinking ability have an important role in handling a problem of the students in school. practicing the stock knowledge at 
the same time the usage of that knowledge can make the problem solving become more effective [1]. it is also showing that students must not only depend in their recent knowledge but also they need to use their stock knowledge for them to widen their knowledge especially in school. students' critical thinking skills are important to boost their self-confidence, improve their conceptual knowledge and the usage of this skill [2]. to overcome the problems of education students must integrate their critical thinking and problem-solving skills [3]. it means that critical thinking and problem-solving ability of the students needs to work together in order to easily solve their problem either it is easy or complicated. meanwhile, it has been observed in a senior high that, there are some students who lack of skills in problem solving attitude and critical thinking ability. usually in school if the students have problems, they cannot solve it immediately instead they become angry, frustrated, stressed or depressed. in that case, the problem will grow bigger and will become complicated. the student will get tired in participating in class discussions, doing their academic tasks, and attending classes. it is essential for a student to develop their problem-solving attitude for them to easily solve their problems and avoid being frustrated, stressed, and especially depressed in their problems.

It is also observed in school that though some students with critical thinking but are not fully developed because they are not confident to show it. in that situation, students are not comfortable being corrected. they'd be bullied by their classmates and result to low their self-esteem in thinking critically. it is important for student to develop their critical thinking ability, so that it can help them to easily handle their problems and to find the best solution of their problems.

In addition, students have critical thinking ability and problem-solving attitude, but the development are not the same. some students have fully developed their critical thinking ability and problem-solving attitude. while other students are need to develop it for them to easily cope up to their problems and to avoid being frustrated, stressed and depresses in their problems.

In the study, the researcher will determine the relationship between problem solving attitude and critical thinking ability of senior high school students.

The study intends to know the level of problem-solving attitude and level of critical thinking ability and their association.

\section{Review of Related Literature}

This study is supported by the different articles from the variables problem solving attitude and critical thinking ability.

Students believe that problem solving is an enjoyable task especially if it is solved [4]. Students problem solving can motivate them to contribute emotionally, honestly and express their personal thoughts in particular problem [5]. Problem solving is very useful for students because they can easily solve their problems by using this method [6]. Students problem solving skills have positively enhance their achievements, skills and confidence [7]. Students are trained to solve problems in order to improve their skills in problem solving and to extend their success rate in mathematics [8]. Students who don't have experience in solving problems are not productive in their work [9]. Problem solving learning is very useful to improve critical thinking skills [10]. 
Teachers exposing students to difficult levels of problems in order to improve their ability in solving problems by their using problem solving skills [11]. Students who experience problems can enhance their positive attitude by using problem solving [12]. Problem solving is more vital if the basis and application of that knowledge are well trained [1]. Students who have high level of problem-solving skills can give better performance in mathematics [13]. Problem solving skill is needed in nursing education and it needs to have further studies to improve this skill [14]. Problem solving can help the students to lessen their stress and anxiety in Mathematics Problem Solving [15]. Problem solving can encourage students to become more motivated by the help of peer learning [16].

Critical thinking is very important in any aspects in life, especially on professional people [17]. Learning critical thinking is very important strategy in learning process [18]. Critical thinking needs to use skills and strategies in order to improve the desired outcomes and to solve the problems they encountered [19]. Students' critical thinking skills can create best solution to their problems [20]. Students' critical thinking skills evaluate the information that they get and the usage of their knowledge, however it needs more practice to become more efficient [21]. In order to become successful learners should enhance their critical thinking abilities, to easily analyze complex situations, generate efficient solutions and make a good decision [22]. Critical thinking helps the students to develop their performance in class [23]. Students who master critical thinking ability can improve their academic performance in school [24]. Developing critical thinking skills of students in English for Specific Purposes classes can enhance their self-confidence and improve their application of knowledge in this skill [2]. Students can enhance their critical thinking skills by participating in a group discussion while solving problems [25]. Students enhance their critical thinking and improve their positive attitude towards chemistry by the use of Modified Useful Learning [26]. Appropriate influencing-based learning activities are social networks and cloud computing put into practice to develop critical thinking [27].

Therefore, there is a correlation between critical thinking and problem-solving skills [28]. Students who experience obstacles in life can improve their critical thinking in problem solving. It helps them to become more motivated and enhance their skills to organize their knowledge [29]. Psychology students need to enhance both critical thinking ability and problem-solving skills to solve complicated problems [3]. Computer engineering students enhance and aim to improve their critical thinking disposition and problem-solving skills to carry out activities and practices [30].

\section{Materials and Methods}

\section{Research Methodology}

This chapter presented the different methods and information that was used in the research study. It includes the research design, research environment, research respondents, research instruments and gathering of data.

\section{Design}

This research study used descriptive design of the variable to determine the relationship between problem solving attitude and critical thinking ability of the students. 


\section{Environment}

The study was conducted in a certain school senior high school in Mandaue City, Cebu, Philippines. The school offered the strands namely HUMSS, ABM, GAS, TVL and STEM. The Senior High School Department has two buildings. The first building is a 3 storey building that consists of 6 rooms and occupied by Grade 11 HUMSS, TVL, GAS, and ABM. While, the second building is a 4 storey building that consist of 8 rooms and occupied by the Grade 12 HUMSS, ABM, GAS, STEM.

\section{Respondents}

The respondents of this research study are the Grade 11 and Grade 12 Senior High School students of each strand (GAS, HUMSS, ABM, TVL-Drafting, and STEM). The study used a complete enumeration since it needs to include all Senior High School students to be the respondents and it has overall respondents of 250 . But out of the 250 respondents only 240 respondents answered.

\section{Instruments}

The researcher used rating scale questionnaire in gathering data and information for it is the appropriate tool in quantitative research. This rating scale was adopted from Problem SolvingStyle Questionnaire by Ranganath Pandit [31] and Assessment of the Critical Thinking Skill of Student by Alan Castle [32]. First was for problem solving attitude and the second was critical thinking ability. The students needed to put a check for their best answer most related about their feelings. The first part was for problem solving attitude that composed of 20 questions and the second part was for critical thinking ability composed of 12 questions. Both questionnaires of part 1 and part 2 used the rating scale, 1-strongly disagree, 2-disagree, 3-agree, 4-strongly agree.

\section{Data Gathering}

The researchers sent a letter request for the school head and advisers of each strand for the permission of conducting the research study. The researcher explained the purpose of the study and distributed the questionnaires to the respondents. After that, the research would give time to the respondents to answer the questionnaire. While the respondents were answering the questionnaire, they can also asked some questions to the researcher regarding to the questionnaire. After the respondents had answered the questionnaire, the researcher would collect the data and give appreciation for cooperating the study. The collected data are used for statistical treatment. The result of statistical treatment served as basis of the analysis, interpretation, conclusion, findings, and recommendation.

\section{Statistical Treatment}

The researcher used two statistical tools, the weighted mean and chi-square. The weighted mean used for treating the means of the indicators of problem solving attitude and critical thinking ability of the students, the sum of the rating made by the respondents are taken and used for chi-square. The chi-square is used to determine the correlation between problem solving and critical thinking ability. 


\section{Results and Discussion}

Table 1: Problem Solving Attitude

\begin{tabular}{|c|c|c|}
\hline Indicators & W. M. & Interp. \\
\hline 1. Most people think that I am objective and logical. & 2.77 & Agree \\
\hline 2. Most people would say that I am emotional and rather motivating. & 2.77 & Agree \\
\hline $\begin{array}{l}\text { 3. Most people believe that I know the details of my job and do it very } \\
\text { accurately. }\end{array}$ & 2.80 & Agree \\
\hline 4. Most people agree that I am a complex and intellectual person. & 2.72 & Agree \\
\hline $\begin{array}{l}\text { 5. I tend to focus on immediate problems and let others worry about the } \\
\text { distant future. }\end{array}$ & 2.61 & Agree \\
\hline 6. I try to please others and need occasional praise. & 2.50 & Disagree \\
\hline $\begin{array}{l}\text { 7. When I face a problem, I try to analyze all the facts and put them in } \\
\text { systematic order. }\end{array}$ & 3.07 & Agree \\
\hline $\begin{array}{l}\text { 8. I'm more interested in long-range implications and often bored with minor } \\
\text { here and now details. }\end{array}$ & 2.70 & Agree \\
\hline 9. I'm usually more people oriented than task oriented. & 2.79 & Agree \\
\hline 10. Before I put energy into project, I want to know what's in it for me. & 3.03 & Agree \\
\hline $\begin{array}{l}\text { 11. I normally solve problems quickly without wasting a lot of time on } \\
\text { details. }\end{array}$ & 2.61 & Agree \\
\hline $\begin{array}{l}\text { 12. When I have a job to do, I do it, even if others' feelings might get hurt in } \\
\text { the process. }\end{array}$ & 2.48 & Disagree \\
\hline 13.I get bored with routine and prefer to deal with new and complicated. & 2.60 & Agree \\
\hline 14. I'm a pretty good judge as to how others feel about problems. & 2.75 & Agree \\
\hline 15. I don't let problems upset me, no matter how difficult they are. & 3.00 & Agree \\
\hline $\begin{array}{l}\text { 16. I like to do things that I do well, but I'm not comfortable trying to learn } \\
\text { new skills. }\end{array}$ & 2.58 & Agree \\
\hline 17. I prefer harmony in a work group ------- otherwise efficiency suffers. & 2.71 & Agree \\
\hline 18. I really enjoy solving new problems. & 2.65 & Agree \\
\hline 19. I am a quick learner, but I don't like theoretical futuristic concepts. & 2.70 & Agree \\
\hline 20. When necessary, I have no trouble making tough, hard-nosed decisions. & 2.69 & Agree \\
\hline Overall Weighted Mean & 2.73 & Agree \\
\hline
\end{tabular}

Source: Pandit, R. (2011), https: //www.scribd.com/doc/67905634/Problem-Solving-StyleQuestionnaire Legend: Strongly Disagree (1-1.75), Disagree (1.76-2.50), Agree (2.51-3.25), Strongly Agree (3.26-4)

Table 1 presents that 20 of the indicators from the variable of problem solving attitude, have three highest weighted mean that was interpreted as Agree. The first highest weighted mean is the indicator, "When I face a problem, I try to analyze all the facts and put them in systematic order", the second highest weighted mean is, "Before I put energy into project, I want to know what's in it for me", and the third highest weighted mean is, "I don't let problems upset me, no matter how difficult they are". On the other hand, there are also three lowest weighted mean in problem solving attitude. The first lowest weighted mean is the indicator, 'When I have a job to do, I do it, even if others' feelings might get hurt in the process", followed by "I try to please others and need occasional praise", and lastly "I like to do things that I do well, but I'm not comfortable trying to 
learn new skills". Meanwhile the overall weighted mean of the problem solving attitude is interpreted as Agree, and it is supported by the other studies. Students' problem method can establish a positive attitude when solving problems [12]. Students worked hard to use their skills in solving problems although they were unable to find a solution determined that they don't give up and they can use their ability to find a solution [4]. Student's problem solving skills is more reliable and increases students learning quality [10]. Therefore, it is evident that problem solving attitude is very important for all of the students in handling problems in life.

Table 2: Critical Thinking Ability

\begin{tabular}{|l|c|c|}
\hline Indicators & W. M. & Interp. \\
\hline $\begin{array}{l}\text { 1. I have learnt more about how to approach complex issues in a variety of } \\
\text { ways. }\end{array}$ & 2.95 & Agree \\
\hline $\begin{array}{l}\text { 2. I have seldom found myself actively engaged in thinking about complex } \\
\text { issues. }\end{array}$ & 2.82 & Agree \\
\hline $\begin{array}{l}\text { 3. I have improved my ability to judge the value of new information on } \\
\text { evidences presented to me. }\end{array}$ & 2.88 & Agree \\
\hline $\begin{array}{l}\text { 4. I have learnt more about how to analyze the key issues in my subject } \\
\text { area. }\end{array}$ & 2.88 & Agree \\
\hline $\begin{array}{l}\text { 5. I have not improved my ability to give sound reason for my beliefs, } \\
\text { opinions, and ideas. }\end{array}$ & 2.55 & Agree \\
\hline $\begin{array}{l}\text { 6. I have developed a more open-minded approach in interpreting, } \\
\text { analyzing and judging alternative points of views. }\end{array}$ & 2.94 & Agree \\
\hline 7. My interest in issues and questions related to subject area has increased. & 2.98 & Agree \\
\hline 8. I have developed a more focused and systematic way of thinking. & 2.93 & Agree \\
\hline $\begin{array}{l}\text { 9. I have learnt more about how to justify why certain procedures are } \\
\text { undertaken in my subject area. }\end{array}$ & 2.90 & Agree \\
\hline $\begin{array}{l}\text { 10. Most tutors have encouraged me to explore the ideas, theories, } \\
\text { assumptions, and produces related to the subject area. }\end{array}$ & 2.90 & Agree \\
\hline $\begin{array}{l}\text { 11. Most tutors have not demonstrated how to think and express myself in } \\
\text { a more reasonable, objective, and evaluative way. }\end{array}$ & 2.49 & Disagree \\
\hline $\begin{array}{l}\text { 12. Most assessments have not stretched my intellectual abilities. } \\
\text { Overall Weighted Mean }\end{array}$ & 2.50 & Disagree \\
\hline
\end{tabular}

Source: Castle, A. (2006), Assessment of the critical thinking skill of student. Science Direct. 12(2), 88-95. https://www.sciencedirect.com/science/article/abs/pii/S1078817405000234

Legend: Strongly Disagree (1-1.75), Disagree (1.76-2.50), Agree (2.51-3.25), Strongly Agree $(3.26-4)$

The table 2 presented that 12 of the indicators from the variable of critical thinking ability have three highest weighted mean that was interpret as Agree. The first highest "My interest in issues and questions related to subject area has increased", the second highest weighted mean is, "I have learn more about how to approach complex issues in a variety of ways", the third highest weighted mean is, "I have developed a more open-minded approach in interpreting, analyzing and judging alternative points of views". In addition, there have three lowest weighted mean. First, "Most tutors have not demonstrated how to think and express myself in a more reasonable, objective, and evaluative way", followed by "Most assessments have not stretched my intellectual abilities", and lastly, "I have not improved my ability to give sound reason for my beliefs, opinions, and ideas". 
While the overall weighted mean of the critical thinking ability is interpreted as Agree and it is supported by some research studies. Students who are given more support can enhance their critical thinking skills and attitude and can maximize their performance [26]. Students who think critically would perform better academically and better ready to fulfill the educational standards [24]. Hence, critical thinking ability is very important for the students in managing and finding ways to solve a particular problem.

Table 3: Problem Solving Attitude and Critical Thinking Ability

\begin{tabular}{|l|c|c|c|}
\hline & Value & Df & Asymp. Sig. (2-sided) \\
\hline Pearson Chi-Square & $1.503 \mathrm{E} 3$ & 792 & .000 \\
\hline Likelihood Ratio & 556.681 & 792 & 1.000 \\
\hline Linear-by-Linear Association & 100.302 & 1 & .000 \\
\hline N of Valid Cases & 240 & & \\
\hline
\end{tabular}

a.850 cells $(100.0 \%)$ have expected count less than 5 . The minimum expected count is .00 .

In this result, the null hypothesis is rejected, because the p-value (0.000) is less than to the significant level (0.05). Therefore, students' problem solving attitude and critical thinking ability is significantly associated to each other. There is a relationship between problem solving attitude and critical thinking ability of the students [28], [29]; and [30].

\section{Conclusions and Recommendations}

\section{Conclusion}

Despite of the challenges and problems that encountered by the students they bravely faced it by using their problem solving attitude and their critical thinking ability. It is shown apparently that having high level of problem solving attitude of students gives them an advantage in their daily lives. They can use it to become wiser in solving different problems that they may encounter especially in complicated problems. Students used their critical thinking for them to have the best solution to the problem that encounter. Meanwhile, the problem solving attitude of the students is needed in order to boost their self-confidence when they encounter problems in life. Problem solving attitude and critical thinking ability of the students have an important factor of solving problems in school and it integrated to each other for it to become handy. Improving these skills will make the student to become more successful in the future.

\section{Recommendations}

Based on the finding of the study, students can identify their level of p9roblem solving attitude and critical thinking ability, they can use it in different problems that they encounter, and they can use it to enhance their skills and ability to solve problems.

Parents can guide their children to maintain their skills in solving problems using their critical thinking ability and problem solving skills.

Teachers can also give guidance to their students and help them to realize that their problem solving skills and critical thinking ability is a important factors especially in solving problems, 
instead they can improve their skills to pursue their dream regards to the problem that they encounter.

\section{Acknowledgements}

First of all, I would like to say thank you to our Almighty God for guiding me and for giving me knowledge, strength and wisdom to exceed the circumstances that I encounter doing this research

To our principal Ms. Juvy M. Sosas for providing a facilities and things to me and also to my costudents

To my beloved adviser Mr. Richard F. Ruelan to guide and motivate me through the trials that I face to finish this research study.

I would like to express my deepest gratitude to my parents to their encouragement, financial assistance as well as their full support to finish this research.

And I take this opportunity to express my sincere thanks for all the people especially to my classmates for their unceasing encouragement, help, knowledge and equipment to finish this research wonderful.

\section{Appendices}

\section{Appendix A}

Direction: Read the statements below. After reading rate your answers using 4-Strongly agree, 3Agree, 2-Disagree, 1-Strongly disagree.

Name:

Gender:

Gr.\& Sec:

\section{Problem Solving Questionnaire}

Age:.

\begin{tabular}{|c|c|c|c|c|}
\hline Statements & 4 & 3 & 2 & 1 \\
\hline 1. Most people think that I am objective and logical. & & & & \\
\hline 2. Most people would say that I am emotional and rather motivating. & & & & \\
\hline 3. Most people believe that I know the details of my job and do it very accurately. & & & & \\
\hline 4. Most people agree that I am a complex and intellectual person. & & & & \\
\hline $\begin{array}{l}\text { 5. I tend to focus on immediate problems and let others worry about the distant } \\
\text { future. }\end{array}$ & & & & \\
\hline 6. I try to please others and need occasional praise. & & & & \\
\hline $\begin{array}{l}\text { 7. When I face a problem, I try to analyze all the facts and put them in systematic } \\
\text { order. }\end{array}$ & & & & \\
\hline $\begin{array}{l}\text { 8. I'm more interested in long-range implications and often bored with minor here } \\
\text { and now details. }\end{array}$ & & & & \\
\hline 9. I'm usually more people oriented than task oriented. & & & & \\
\hline 10. Before I put energy into project, I want to know what's in it for me. & & & & \\
\hline 11. I normally solve problems quickly without wasting a lot of time on details. & & & & \\
\hline
\end{tabular}


12. When I have a job to do, I do it, even if others' feelings might get hurt in the process.

13. I get bored with routine and prefer to deal with new and complicated.

14. I'm a pretty good judge as to how others feel about problems.

15. I don't let problems upset me, no matter how difficult they are.

16. I like to do things that I do well, but I'm not comfortable trying to learn new skills.

17. I prefer harmony in a work group ------- otherwise efficiency suffers.

18. I really enjoy solving new problems.

19. I am a quick learner, but I don't like theoretical futuristic concepts.

20. When necessary, I have no trouble making tough, hard-nosed decisions.

Note: This research instrument is adapted from the article of Pandit, R. (2011) entitled Problemsolving style questionnaire.

\section{Appendix B}

\section{Critical Thinking Ability Questionnaire}

\begin{tabular}{|c|c|c|c|c|}
\hline Statements & 4 & 3 & 2 & 1 \\
\hline 1. I have learnt more about how to approach complex issues in a variety of ways. & & & & \\
\hline 2. I have seldom found myself actively engaged in thinking about complex issues. & & & & \\
\hline $\begin{array}{l}\text { 3. I have improved my ability to judge the value of new information on evidences } \\
\text { presented to me. }\end{array}$ & & & & \\
\hline 4. I have learnt more about how to analyze the key issues in my subject area. & & & & \\
\hline $\begin{array}{l}\text { 5. I have not improved my ability to give sound reason for my beliefs, opinions, } \\
\text { and ideas. }\end{array}$ & & & & \\
\hline $\begin{array}{l}\text { 6. I have developed a more open-minded approach in interpreting, analyzing and } \\
\text { judging alternative points of views. }\end{array}$ & & & & \\
\hline 7. My interest in issues and questions related to subject area has increased. & & & & \\
\hline 8. I have developed a more focused and systematic way of thinking. & & & & \\
\hline $\begin{array}{l}\text { 9. I have learnt more about how to justify why certain procedures are undertaken } \\
\text { in my subject area. }\end{array}$ & & & & \\
\hline $\begin{array}{l}\text { 10. Most tutors have encouraged me to explore the ideas, theories, assumptions, } \\
\text { and produces related to the subject area. }\end{array}$ & & & & \\
\hline $\begin{array}{l}\text { 11. Most tutors have not demonstrated how to think and express myself in a more } \\
\text { reasonable, objective, and evaluative way. }\end{array}$ & & & & \\
\hline 12. Most assessments have not stretched my intellectual abilities. & & & & \\
\hline
\end{tabular}

Note: This research instrument is adapted from the article of Castle, A. (2006). Assessment of the critical thinking skill of student.

\section{References}

[1] Carzon, Z. (2007). A problem with problem solving: Teaching Thinking Without Teaching Knowledge. The Mathematics Educator, 17(2), 7-14.

https://www.google.com/url?sa=t\&source=web\&rct=j\&url=https://files.eric.ed.gov/fulltext/EJ84 1561.pdf\&ved 
[2] Tuzlukova, V., \& Prabhukanth, K.U. (2018). Critical thinking and problem solving skills: English for Science Foundation Program Students' Perspectives. Collection of Papers of the Faculty of Philosophy, 47(3), 37-58. Doi: 10.5937/ZRFFP48-18664

[3] Toharudin, U. (2015). Critical thinking and problem solving skills: How these Skills are needed in Educational Psychology?. International Journal of Science and Research, 78(96), 1-4. Doi: 10.21275/ART20171836

[4] Ozturk, T., \&Guven, B. (2015). Evaluating students' beliefs in problem solving process: A Case Study. EURASIA Journal of mathematics, Science \& Technology Education, 12(2), 411-429.

[5] Leader, L., \& Middleton, J. (2004). Promoting critical-thinking dispositions by using problem solving in middle school mathematics. Research in Middle Level Education Online, 28(1), 1-13. Doi: $10.1080 / 19404476.11658174$

[6] Nasriah, L. (2017). Problem solving methods to improve understanding of learning social subject matter for students of VII of SMP Negeri2 Tigaraksa, Indonesia. European Journal of Education Studies, 3(4), 1-8. Doi: 10.5281/zenodo.345621

[7] Gok, T. (2014). Students' achievement, skill and confidence in using stepwise problem-solving strategies.Eurasia Journal of Mathematics, Science \& Technology Education, 10(6), 617-624. https://www.google.com/url?sa=t\&source=web\&rct=j\&url=http://www.ejmste. com/StudentsAchievement-Skill-and-nConfidence-in-Using-Stepwise-nProblem-Solving-Strategies, 74874,0,2. html \&ved

[8] Saygili, S. (2017). Examining the problem solving skills and the strategies used by high school students in solving non-routine problems. E-Internaltional Journal of Educational Research, 8(2), 91-114.

https://www.google.com/url?sa=t\&source=web\&rct=j\&url= http://www.e-ijer.com/download/article-file/338828\&ved

[9] Rohmah, M., \&Sutiaro, S. (2017). Analysis problem solving in mathematical using theory new man. EURASIA Journal of Mathematics, Science and Technology Education, 14(2), 671-681. Doi: 10.12973/ejmste/80630

[10] Utami, B., Saputro, S., Ashadi, Masykuri, M., \&Sutanto, A. (2017). Implementation of problem solving with concept map to improve critical thinking skills and chemistry learning achievement. International Conference on Teacher Training and Education, 158(1), 1-10. https: $/ / \mathrm{www}$.google.com/url?sa=t\&source=web\&rct=j\&url=https://download.atlantis-press.com/article 125885745.pdf\&ved

[11] Shakhman, L., \& Barak, M. (2019). The physics problem-solving taxonomy (PPST): Development and Application for Evaluating Student Learning. EURASIA Journal of Mathematics, Science and Technology Education, 15(11), 1-16. https//doi.org/10.29333/ejmste/109266

[12] Chao, J.Y., Tzeng, P.W., \& Po, H.Y. (2016). The study of problem solving process of E-book PBL course of atayal senior high school students in taiwan. EURASIA Journal of Mathematics Science and Technology Education, 13(3), 1001-1012. Doi: 10.12973/eurasia.2017 .00654a

[13] Alcantara, E. \&Bacsa, J.M. (2017). Critical thinking and problem solving skills in mathematics of grade-7 public secondary students. Asia Pacific Journal of Multidisciplinary Research, 5(4), 21-27. https://www.google.com/url?sa=t\&source=web\&rct=j\&url= http://www .apjmr.com/wpcontent/uploads/2017/12/APJMR-2017.5.4.2.03.pdf\&ved

[14] Ancel, G. (2016). Problem-Solving Training: Effects on the Problem-Solving Skills and SelfEfficacy of Nursing Students. Eurasian Journal of Educational Research, 64, 231-246, http://dx.doi.org/10.14689/ejer.2016.64.13

[15] Caballero, A., Blanco, L., \& Guerrero, E. (2011). Problem solving and emotional education in initial primary teacher education. Eurasia Journal of Mathematics, Science \& Technology Education, 7(4), 281-292.

https://www.google.com/url?sa=t\&source=web\&rct =j\&url=http://www.ejmste.com/pdf 
[16] Temur, O.D. (2012). Analysis of prospective classroom teachers' teaching of mathematical modeling and problem solving. Eurasia Journal of Mathematics, Science \& Technology Education, 8(2), 83-93. https://www.google.com/url?sa=t\&source=web\&rct=j\&url= https://pdfs.semanticscholar.org/f457/10ccd7558d957d584ae6fdd5ef982ecc6575.pdf\&ved

[17] Karakoc, M. (2016). The significance of critical thinking ability in terms of education. International Journal of Humanities and Social Science, 6(7), 81-85. https://www.google.com/url?sa=t\&source=web\&rct=j\&url=https://pdfs.semanticscholar.org

[18] Llyod, M. \& Bahr, N. (2010). Thinking critically about critical thinking in higher education. International Journal for the Scholarship of Teaching and Learning, 4(2), 2-16. https://www.researchgate.net/publication/228513767

[19] Zulmaulida, A., Wahyudin, M., \&Dahlan, J.A. (2018). Watson-glaser's critical thinking skills. Journal of Physics, 1-6. Doi: 10.1088/1742-6596/1028/1/012094

[20] Birgili, B. (2015). Creative and critical thinking skills in problem-based learning environments. Journal of Gifted Education and Creativity, 2(2), 71-80. Doi: 10.18200/JGEDC.2015214253

[21] Snyder, L.G., \&Synder, M. (2008). Teaching critical thinking and problem solving. The Delta Pi Espilson Journal, 50(2), 90-99. https://www.google.com/url?sa=t\& source=web\&rct=j\&url=https://www.scirp.org

[22] Zare, M., \&Biria, R. (2018). Contributory role of critical thinking in enhancing reading comprehension ability of Inanian ESP students. International Journal of Research in English Education, 3(3), 22-28. Doi:10.29252/ijree.3.3.21

[23] Nold, H. (2017). Using critical thinking teaching methods to increase students success: An Action Research Project. International Journal of Teaching and Learning in Higher Education, 29(1), 17 32. https://www.google.com/url?sa=t\&source=web\&rct=j\&url=https://files.eric.ed.gov

[24] Changwong, K., Sukkamart, A., \&Sisan, B. (2018). Critical thinking skill development: Analysis of a New Learning Management Model for Thai High School. Journal of International Studies, 11(2), 37-48. Doi: 10.14254/20718330. /11-2/3

[25] Saputra, M.D., Joyoatmojo, S., Wardani, D.K. (2019). Developing critical-thinking skills through the collaboration of Jigsaw model with problem-based learning model. International Journal of Instuction, 12(1), 1077-1094. https://doi.org/10.29333/iji.2019.121699

[26] Marasigan, A., \& Espinosa, A. (2014). Modified useful-learning approach: Effects on Students' Critical Thinking Skills and Attitude towards Chemistry. International Journal of Learning, Teaching and Educational Research, 1(1). https://www.ijlter. org/index. php /ijlter/article/view/9/4

[27] Thaiposri, P., \&Wannapiroon, P. (2015). Enhancing students' critical thinking skills through teaching and learning by inquiry-based learning activities using social network and cloud computing. Procedure-Social and Behavioral Science,174(1), 2137-2144. Doi: 10.1016/j.sbspro.2015.02.013

[28] Rodzalan, S., \&Saat, M. (2018). A mixed-method analysis on students' critical thinking and problem solving skill development in malaysian public universities. International PostGraduate Conference on Applied Science \& Physics, 1-9. Doi: 10.1088/1742-6596/1/012015

[29] Belecina, R., \&Ocampo, J. Jr. (2018). Effecting change on students' critical thinking in problem solving. Educare: International Journal for Educational Studies, 10(2), 109-116. https://www.reseachgate.net/publication/323141477

[30] Ozyurt, O. (2015). Examining the critical thinking dispositions and the problem solving skills of computer engineering students. Eurasia Journal of Mathematics, Science \& Technology Education, 11(2), 353-361.

https://www.google.com/url?sa=t\&source=web\&rct= j\&url=http://www.ejmste.com/Examiningthe-Critical-Thinking-Dispositions-and-the-Problem-Solving-Skills-of-Computer-EngineeringStudents,51522,0,2.html\&ved 
[31] Pandit, R. (2011). Problem-solving style questionnaire. https: //www.scribd.com/doc/ 67905634/Problem-Solving-Style-Questionnaire

[32] Castle, A. (2006). Assessment of the critical thinking skill of student. Science Direct. 12(2), 88-95. https: //www.sciencedirect.com/science/article/abs/pii/S1078817405000234

${ }^{*}$ Corresponding author.

E-mail address: monevajerald5 @gmail.com 